\title{
DOES FAMILY SOCIAL SUPPORT AFFECT STARTUP BUSINESS ACTIVITIES?
}

\author{
Nurlaily Ferina, Aini Edlyn Khurotul, Asmoro Priandhita Sukowidyanti* \\ Faculty of Administrative Science, Universitas Brawijaya, Indonesia \\ *E-mail: priandhita.asmoro@gmail.com
}

\begin{abstract}
In recent years, StartUp has shown a considerable progress in Indonesia. Although most of the StartUps are newly established companies in phase to find the right markets, the StartUps are expected to contribute to the economy and solve local problems. In Indonesia most of the StartUps are still in the idea stage. Therefore, they have no profit, loss, or even failure. It causes the StartUps to be difficult in gaining trust from investors. To overcome these problems, support from various parties is necessary for the development of StartUp activities. One of them is a support from family (Family Social Support). Previous studies have shown that family support contributes to the success of an entrepreneur. However, there has been no research on the relationship between family support with StartUp activities, especially in developing countries like Indonesia. This study examined the influence of family social support in the form of financial capital support, social capital, human capital, physical capital, and family cohesiveness on StartUp activities in Indonesia by using Poisson regression analysis. The results showed that family cohesiveness had a significant effect on the increase of StartUp activities.
\end{abstract}

\section{KEY WORDS}

Family social support, startup activities, Indonesia.

Entrepreneurship is an issue that has been talked about in several years. All type of companies, including big companies and newly-established companies-or known as StartUps - are showing considerable growth in many countries around the world. On average, StartUps in the United States increased from $0.28 \%$ in 2014 to $0.31 \%$ in 2015 per month (www.kauffman.org, 2015). In Ireland, the number of new businesses increased by $21 \%$ in the first half of 2016 compared to the previous year. In Asia, the the highest number of StartUps was found in India, which was at 3,475 (www.startupranking.com, 2017).

Similar with many developed countries, the StartUp businesses in Indonesia also show a rapid increase in number. Every year, and even every month, many new StartUp owners appear. The data showed that the number of StartUp businesses in Indonesia currently reached 1,454 and it was ranked as third in the world after the United States and India (www.startupranking.com, 2017). In other words, according to the survey, the number of StartUps in Indonesia is the highest in the ASEAN region. Even some StartUp businesses in Indonesia occupied TOP 100 StartUps in the world, namely: Tokopedia, Bukalapak, Blibli, and Traveloka (www.startupranking.com, 2017). Another research institute, CHGR in 2016, predicted that StartUp digital businesses in Indonesia will grow 6.5 times by 2020 and estimated that there would be 13,000 StartUp businesses which was running in the year.

StartUps in Indonesia can be classified into three groups: game creator StartUp, educational application StartUp and trading StartUp, such as e-commerce trading and information trading (www.dailysocial.net, 2016). The three groups are predicted to have a potential market and growing rapidly in Indonesia. Moreover, nowadays, there has been established a lot of communities of StartUp founders in Indonesia. These communities ease the founders to share, guide, and even attract the investors, such as Bandung Digital Valley (bandungdigitalvalley.com), Jogja Digital Valley (jogjadigitalvalley.com), Inkubator Bisnis in Semarang (www.ikitas.com), Stasion (stasion.org) which is a container for local startUps in Malang city, etc.

StartUps refer to recently operated companies. Most of these companies are newlyestablished companies and are in a development and research phase to find the right markets 
(Calopa et al., 2014). StartUp businesses are usually, though not always, related to high technology because most of their products are in the form of digital applications. Seeing a large number of StartUps and their rapid growth in Indonesia, these businesses are expected to solve local problems and can also provide a positive contribution to the economic growth and community's welfare. Various studies showed that entrepreneurship could strengthen economic growth and reduced unemployment through increased competition. Hence, business productivity and new technological innovations would continue to grow (Koellinger and Thurik, 2012; Fritsch, 2008). Therefore, with more and more growing and successful StartUps, they are expected to reduce unemployment and poverty and can provide job openings for job seekers.

Given the considerable potential of StartUp's roles, many countries provide support to eliminate obstacles on StartUps, with the ultimate goal of increasing the overall number of StartUps in their economies. One of the obstacles to a successful StartUp is financing. In Indonesia, many StartUps are still in the idea stage, so it has no profit and has a high level of risk. This stage is known as the valley of death because many StartUps experience a loss or even a failure in this stage. It makes StartUps become difficult to obtain funding because funding agencies such as venture capital, banks or other non-bank financial institutions have not wanted to give capital investment or loan. To overcome these problems, the support of various parties is needed by the StartUps to at least be out of the valley of death stage. Government support at this stage can be provided through a funding scheme that can facilitate and encourage StartUp business actors to move to the next step. In addition to government support, a good and strong business model and family support are essential to the development of StartUp activities.

Previous research had shown that family support contributed to the success of an entrepreneur in the family business (Koropp et al., 2013; Rodriguez et al., 2009), building social networks (Newbert et al., 2013; Grossman et al., 2012), and the success of MSMEs (Parinduri, 2014; Spence et al, 2003). Although many studies had linked the role of family support to entrepreneurial success, there has been no research related to family support relationships with StartUp activities, especially in a developing country like Indonesia.

In this study, StartUp activities are defined as the individual behaviors or activities in the process of starting a new venture (Carter et al., 2004 and Gartner et al., 2004 in Edelman et al., 2016). Family social support in the form of social capital, financial capital, human capital, physical capital, and family cohesiveness are categorized into tangible and intangible family support. Family cohesiveness is categorized as intangible family support such as the willingness of families to listen or to empathize (Adams et al., 1996 in Edelman et al., 2016). On the other hand, the other supports like social capital, financial capital, human capital, and physical capital are categorized as tangible support aimed to solve a problem (Manolova et al, 2014). Based on this background, in this study, we examined the influence of family social support on StartUp activities in Malang, Indonesia.

\section{LITERATURE REVIEW}

A StartUp was a temporary organization that was formed with the aim to find a repeatable and scalable business model (Blank, 2012). Meanwhile, Ries (2011) defined StartUp as an institution created to create new and innovative products or services in a state of high uncertainty. StartUp products and consumers are not known from the beginning. This is different from the characteristics of MSMEs (Micro-, Small- and Medium-scale Enterprises) which are to serve the existing market segmentation (known customer) with the existing products (known product). StartUps are oriented towards sustainable growth, while MSMEs are oriented to profit. Therefore, StartUps always strive to create new innovations, develop new consumer shares, cultivate new needs from the community, determine new business opportunities, and always pursue challenges. StartUps are riskier than MSMEs because of the possibility to experience greater failure. StartUps will become small businesses if their business models have been found, generated profit and have a fixed team.

The high uncertainty that StartUps face require solutions to reduce the risk. In other words, a scheme or a model is needed to solve the problems that StartUps face in order to 
minimize StartUp failures. This is because of the important role of StartUps in sustaining the economy of a country, including in Indonesia. Therefore, it is necessary to do research to examine the issues related to StartUp. Studies related to StartUps in developing countries have been more often associated with external factors, such as technology utilization (Audretsch and Acs, 1994), accounting systems (Davila and Foster, 2004), management systems (DelVecchio et al, 2014), investment policies (Nanda and Kropf, 2012), and economics (Boadway and Trembley, 2003). There are still a few number of researches that relate StartUps to internal factors such as family social support. This is because external factors are considered to have a greater share of the success of StartUp businesses than internal factors, especially family support. In fact, the role of the family cannot be ignored in the course of the success of StartUps through the valley of death stage. StartUps as pioneering ventures still do not have enough trust from stakeholders. Therefore, they need internal support, especially from family, to start and develop StartUp businesses.

Social support was the perception or experience of being loved, cared for by others, valued, and was a part of the mutually supportive social network (Taylor, 2011 in Edelman et al., 2016). Social support can come from work environments and non-work environments. Family is a social support comes from the most important non-working environment. Aldrich and Cliff (2003) argued that family had the potential to have a profound effect on the company.

The focus of this research is family social support in assisting StartUp business activities. Kim et al. (2013) stated that social support from family was very important to start a business. Family social support can be supports in the form of social capital, financial capital, human capital, physical capital, and family cohesiveness.

Social capital referred to a network of closely related personal and organizational relationships (Bastie et al., 2013). Strong relationships tended to be long-term relationships based on frequent contacts, such as those between family members, friends, or communities (Coleman, 1988 in Manolova et al., 2014). Conversely, weak bonds tended to be short-term relationships based on rare interactions and exchanges (Granovveter, 1973 in Manolova et al., 2014). In this study, social capital referred to a special form of internal social capital developed through dynamic relationships and mutual trust between family members (Dyer et al., 2014). Family social capital might have a strong influence on the business creation process, even when the family was not directly involved in entrepreneurial initiatives (Aldrich and Cliff, 2003; Steier, 2007).

H1: Family social capital support has a significant effect on StartUp activities.

Financial capital is very important for a new company. With the availability of entrepreneurial financial capital, a company can be more flexible to perform a wider StartUp activities. But since StartUp is a new business and lack of guarantees and credit history, it will be difficult for StartUp to get a loan from the Bank. Financially, newborn entrepreneurs typically obtained early-stage funding from friends and family (Winborg and Landstrom, 2001). A recent study showed that there was a positive influence of family involvement on StartUp debt financing (Chua et al., 2011).

H2: Family financial capital support has a significant effect on StartUp activities.

The concept of human capital was rooted in the idea that people had skills, experience

and knowledge that had economic value for themselves and their company (Cetindamar et al., 2012). Entrepreneurs with business experience had knowledge of the various activities associated with starting a business, how to develop contacts with customers and investors, how to collect and allocate resources, and how to attract and retain employees (Grichnik et al., 2014). StartUp owners, especially newborns, usually lacked managerial experience. Therefore, young entrepreneurs viewed the family as a way to overcome the lack of aspects of human capital (Hoang and Antoncic 2003). Family human capital was defined as the knowledge, skills and abilities of each family member (Danes et al., 2009). Family human capital was a potential resource for the creation of new business and for the development of the company (Sorenson, 2007).

H3: Family human capital support has a significant effect on StartUp activities. 
Physical capital consisted of family assets such as the use of a family's house as the business office, family's vehicle, phone and computer that could be used to start a new business (Dyer et al., 2014).

H4: Family physical capital support has a significant effect on StartUp activities.

Family Cohesiveness referred to the level of connectedness and emotional bonding between family members (Laspita et al., 2012). Families with high cohesiveness were characterized by intense norms, behavior, understanding and intense emotional connection (Granovveter, 1992). Newbert et al. (2013) stated that newborn entrepreneurs would look for individuals who had strong emotional attachments with them for various forms of support during the StartUp creation process. Family cohesiveness is crucial for launching a StartUp with young owners, because they still have little entrepreneurial experience and do not yet have a strong business network. Therefore, they have to rely on family's connections.

H5: Family cohesiveness has a significant effect on StartUp activities.

\section{METHODS OF RESEARCH}

The sample of this research was the owners or creators of StartUps in Malang area, East Java, Indonesia. The reason for choosing StartUps in Malang area, East Java, Indonesia as the object of research was because of the development of StartUp communities in Malang which shows an increasing appearance of the emerging StartUps. Questionnaires were distributed at 100 StartUps in Malang, East Java, Indonesia and the effective rate of the data used was $96 \%$ or 96 respondents. The variables in this study consisted of dependent variable and independent variable. The dependent variable proposed in this study was StartUp Activities by adopting Edelman et al's research (2016) which consisted of 9 stages (1) Thinking about the first business ideas; (2) Formulating business planning; (3) Identifying market opportunities; (4) Looking for potential partners; (5) Buying equipment; (6) Developing products; (7) Discussing with potential customers; (8) Applying for funding to financial institutions; (9) Determining when a business will run. On the other hand, the independent variable for this research was family social support which was adopted from Manoloval et al's (2014) and Lansberg and Astrachan's (1994) research which consisted of (1) financial capital, measured by 3 items; (2) social capital, measured by 2 items; (3) human capital, measured by 3 items; (4) physical capital, measured by 2 items and (5) family cohesiveness, measured by 3 items. The independent variable used the Likert scale of 1 to 5 points, where 1 meant "strongly disagree" and 5 meant "strongly agree". Hypothesis testing has been conducted, which aimed to determine the influence of family social support through its variables on the StartUp activities (Kim et al., 2014). The researchers tested the relationship between these variables by using Poisson Regression analysis because the dependent variable was the number of business activity stages (Edelman et al, 2016).

\section{RESULTS OF STUDY}

This study used questionnaire as one of the instruments of research, therefore, its reliability and validity needed to be tested.

Table 1 - Reliability Test Results

\begin{tabular}{llll}
\hline No & Variable & Cronbach Alpha Value & Detail \\
\hline 1 & Financial Capital & 0.851 & Reliable \\
\hline 2 & Social Capital & 0.937 & Reliable \\
\hline 3 & Human Capital & 0.908 & Reliable \\
\hline 4 & Physical Capital & 0.734 & Reliable \\
\hline 5 & Family Cohesiveness & 0.840 & Reliable \\
\hline
\end{tabular}

Reliability test was used to test whether the respondent's answer to a question in this research questionnaire was consistent or not random. Ghozali (2013: 48) explained that a construct or a variable was said to be reliable if its Cronbach Alpha value was $>0.70$. Based on 
Cronbach statistical test results in Table 1, it was known that the Cronbach Alpha value of each variable used in this study was greater than 0.70 . Therefore, all the variables used in the research could be said as reliable.

A questionnaire was said to be valid if the question on the questionnaire was able to reveal something that would be measured by the questionnaire. Validity test was done by doing a Bivariate correlation analysis between each score indicator with a total score of the construct. Validity test was done by comparing the significance value of test result and the significance level of $5 \%$. Based on the test conducted as in Table 2, the value of Sig. of each indicator against the sig. value of construct total score was less than 0.05 . Thus, each attribute or statement item in this questionnaire could be said to be valid.

Table 2 - Validity Test Results

\begin{tabular}{llll}
\hline No & Item & Sig. Value & Detail \\
\hline 1 & Financial Capital 1 & 0.00 & Valid \\
\hline 2 & Financial Capital 2 & 0.00 & Valid \\
\hline 3 & Financial Capital 3 & 0.00 & Valid \\
\hline 4 & Social Capital 1 & 0.00 & Valid \\
\hline 5 & Social Capital 2 & 0.00 & Valid \\
\hline 6 & Human Capital 1 & 0.00 & Valid \\
\hline 7 & Human Capital 2 & 0.00 & Valid \\
\hline 8 & Human Capital 3 & 0.00 & Valid \\
\hline 9 & Physical Capital 1 & 0.00 & Valid \\
\hline 10 & Physical Capital 2 & 0.00 & Valid \\
\hline 11 & Family Cohesiveness 1 & 0.00 & Valid \\
\hline 12 & Family Cohesiveness 2 & 0.00 & Valid \\
\hline 13 & Family Cohesiveness 3 & 0.00 & Valid \\
\hline 14 & Family Cohesiveness 4 & 0.00 & Valid \\
\hline
\end{tabular}

The research questionnaire was distributed to the students of the StartUp communities in Malang Raya. Questionnaires that have been filled and received by researchers were as many as 100 questionnaires. However, only 96 questionnaires or $96 \%$ which could be processed and analyzed because the 4 questionnaires returned to the researcher were incomplete.

Analysis on demographic profiles of respondents was done to determine the background differences of each respondents, in this case were StartUp business actors who were members of the StartUp community. Demographic profiles consisted of age, gender, marital status, parental employment status, educational status, and the department or study program being pursued. Based on Table 3, it was known that the respondents were still in productive age, where the youngest respondent was 17 years old and the oldest was 30 years old. The majority of respondents in this study was in the age range of 17 years to 21 years, which was amounted to $88.54 \%$ or 85 respondents. Meanwhile, the remaining 11 respondents or $11.46 \%$ were in the age range of 22 years to 30 years. Most of the respondents was 20 years old, which was amounted to 31 respondents. On the contrary, the least of the respondents was 30 years old, which was amounted to 1 respondent. Meanwhile, based on gender, the number of male respondents was 49 respondents and the number of female respondents was 47 respondents. Based on marital status, the majority of respondents was not married (94 respondents) or $97.9 \%$ of respondents. Meanwhile, based on the parental employment status, it was shown that there were only 2 respondents whose parents were not employed, 27 respondents whose both parents were employed, and 12 respondents whose only their mothers who were employed. The majority of respondents was consisted of those whose only his father who were employed, which was amounted to 55 people or $57.3 \%$. Based on educational status, the majority of the respondents were in their bachelor/S-1 degree, which was amounted to 90 respondents or 93,8\%. Most of them was taking Business Administration Study program, which was amounted to 31 respondents or $32,3 \%$.

This research also attempted to map the StartUp business profile of respondents. Based on Table 4, it was known that the majority of 79 respondents or $82.3 \%$ had never worked as employees before starting a StartUp business. Meanwhile, 68 respondents or $70.8 \%$ had parents who worked as entrepreneurs, and the rest of 28 respondents or $29.2 \%$ did not have 
parents who worked as entrepreneurs. When running StartUp business, $62.5 \%$ or 60 respondents had attended training or seminars related to StartUp business, while the rest of $37.5 \%$ or 36 respondents never attended training or seminars. There were many people who mativated the respondents in running the StartUp business.

Table 3 - Demographic Profile of Respondents

\begin{tabular}{|c|c|c|}
\hline & Frequency $(\mathrm{N}=96)$ & $\%$ \\
\hline \multicolumn{3}{|l|}{ Age } \\
\hline 17 & 2 & 2.1 \\
\hline 18 & 18 & 18.8 \\
\hline 19 & 14 & 14.6 \\
\hline 20 & 31 & 32.3 \\
\hline 21 & 20 & 20.8 \\
\hline 22 & 5 & 5.2 \\
\hline 23 & 3 & 3.1 \\
\hline 25 & 2 & 2.1 \\
\hline 30 & 1 & 1.0 \\
\hline \multicolumn{3}{|l|}{ Gender } \\
\hline Male & 49 & 51.0 \\
\hline Female & 47 & 49.0 \\
\hline \multicolumn{3}{|l|}{ Marital Status } \\
\hline Single & 94 & 97.9 \\
\hline Married & 2 & 2.1 \\
\hline \multicolumn{3}{|l|}{ Parental Employment Status } \\
\hline Only the father who is employed & 55 & 57.3 \\
\hline Only the mother who is employed & 12 & 12.5 \\
\hline Both of them are employed & 27 & 28.1 \\
\hline Both of them are not employed & 2 & 2.1 \\
\hline \multicolumn{3}{|l|}{ Educational Status } \\
\hline In the process of pursuing S1 & 90 & 93.8 \\
\hline In the process of pursuing S2 & 1 & 1.0 \\
\hline Senior /Vocational High School & 2 & 2.1 \\
\hline Have gained the title of S1 degree & 3 & 3.1 \\
\hline \multicolumn{3}{|l|}{ Department/Study Program } \\
\hline Business Administration & 31 & 32.3 \\
\hline Public Administration & 9 & 9.4 \\
\hline International Business & 4 & 4.2 \\
\hline Economics & 1 & 1.0 \\
\hline Management & 2 & 2.1 \\
\hline Tourism & 5 & 5.2 \\
\hline Urban and Regional Planning & 1 & 1.0 \\
\hline Taxation & 5 & 5.2 \\
\hline Farming & 5 & 5.2 \\
\hline Information System & 4 & 4.2 \\
\hline Informatics Engineering & 8 & 8.3 \\
\hline Civil Engineering & 1 & 1.0 \\
\hline Fisheries Technology & 1 & 1.0 \\
\hline Others & 19 & 19.8 \\
\hline
\end{tabular}

The majority was motivated by school friends or lecturers, which was amounted to 30 respondents or $31.3 \%, 26$ respondents or $27.1 \%$ was motivated by parents, and 20 respondents or $20.8 \%$ was motivated by successful public figures. The majority of StartUp business that was initiated was the first StartUp, which was 55 respondents or $57.3 \%$, the second StartUp was 23 respondents, the third Startup was 17 respondents, and the fourth StartUp was 1 respondent. A total of 52 respondents or $54.2 \%$ stated that they had yet experienced a failure when pioneering StartUp business, and the rest of 44 respondents stated that they never experienced failure. Meanwhile, the most widely used StartUp type were: Food \& Beverage, which amounted to 25 respondents and IT Service \& Solutions, which amounted to 15 respondents. StartUp business was divided into a StartUp that was run independently or alone, and a StartUp that was run with teams. 6 respondents or $6.3 \%$ said that their StartUp 
businesses were run without team members. On the other hand, the StartUp Businesses run by 1 team member was 7 respondents (7,3\%), 2 members were 15 respondents $(15,6 \%), 3$ members were 31 respondents (32,3\%), 4 members were 21 respondents $(21.9 \%), 5$ members were 6 respondents $(6.3 \%), 6$ members were 7 respondents $(7.3 \%), 7$ members were 1 respondent $(1.0 \%), 15$ members were 1 respondents $(1.0 \%)$, and 38 members were 1 respondent $(1.0 \%)$.

Table 4 - Socio-economic Profile of Respondents

\begin{tabular}{|c|c|c|}
\hline & Frequency $(\mathrm{N}=96)$ & $\%$ \\
\hline \multicolumn{3}{|l|}{ Has ever worked as an employee } \\
\hline Yes & 17 & 17.7 \\
\hline No & 79 & 82.3 \\
\hline \multicolumn{3}{|l|}{ Seminar or Training } \\
\hline Yes & 60 & 62.5 \\
\hline No & 36 & 37.5 \\
\hline \multicolumn{3}{|l|}{ Parents work as enterpreneurs } \\
\hline Yes & 68 & 70.8 \\
\hline No & 28 & 29.2 \\
\hline \multicolumn{3}{|l|}{ Motivators } \\
\hline Self-motivated & 3 & 3.1 \\
\hline Teacher/Lecturer & 7 & 7.3 \\
\hline Others & 2 & 2.1 \\
\hline Parents & 26 & 27.1 \\
\hline Partner & 1 & 1.0 \\
\hline Successful Public Figures & 20 & 20.8 \\
\hline Biological Sibling (younger or older) & 1 & 1.0 \\
\hline Relatives outside the core family & 5 & 5.2 \\
\hline Bestfriend & 1 & 1.0 \\
\hline School/College Friends & 30 & 31.3 \\
\hline \multicolumn{3}{|l|}{ Failure } \\
\hline Yes & 52 & 54.2 \\
\hline No & 44 & 45.8 \\
\hline \multicolumn{3}{|l|}{ StartUp number } \\
\hline 1 & 55 & 57.3 \\
\hline 2 & 23 & 24.0 \\
\hline 3 & 17 & 17.7 \\
\hline 4 & 1 & 1.0 \\
\hline \multicolumn{3}{|l|}{ Type of StartUp } \\
\hline Agriculture & 1 & 1.0 \\
\hline E-Commerce & 6 & 6.3 \\
\hline E-marketing & 2 & 2.1 \\
\hline Education & 4 & 4.2 \\
\hline Fashion \& Beauty & 8 & 8.3 \\
\hline Food \& Beverage & 25 & 26.0 \\
\hline Healthcare & 3 & 3.1 \\
\hline IT Services \& Solutions & 15 & 15.6 \\
\hline Lainnya & 13 & 13.5 \\
\hline Social Enterprise & 8 & 8.3 \\
\hline Transportation & 2 & 2.1 \\
\hline Travel \& Tourism & 8 & 8.3 \\
\hline WordPress Theme & 1 & 1.0 \\
\hline \multicolumn{3}{|l|}{ Number of team members } \\
\hline 0 & 6 & 6.3 \\
\hline 1 & 7 & 7.3 \\
\hline 2 & 15 & 15.6 \\
\hline 3 & 31 & 32.3 \\
\hline 4 & 21 & 21.9 \\
\hline 5 & 6 & 6.3 \\
\hline 6 & 7 & 7.3 \\
\hline 7 & 1 & 1.0 \\
\hline 15 & 1 & 1.0 \\
\hline 38 & 1 & 1.0 \\
\hline
\end{tabular}


There are five assumptions that must be met if a study uses Poisson Regression, namely:

- Dependent variable must be discrete and consists of count data.

Dependent variable in this research was StartUp Activities in the form of dichotomic data, which was StartUp activities stages that consisted of: 1) thinking of first business ideas, 2) formulating business planning, 3) identifying market opportunities, 4) finding potential partners, 5) buying equipment , 6) developing products, 7) discussing with potential customers, 8) applying for funding to financial institutions, 9) determining when the business will run. It showed that the dependent variable in this research was in the form of discrete data, that was variables which were in the form of categorization data or differentiated or classified certain types.

- Have one or more independent variables that can be measured on a continuous scale (ordinal scale, interval scale, or ratio scale) or nominal scale (dichotomous).

This study had five independent variables, namely: Financial Capital, Social Capital, Human Capital, Physical Capital, and Family Cohesiveness which was measured on a continuous scale in the form of ratio scale.

- Dependent Variables are Poisson distributed

Kolmogorov-Smirnov normality test with a significance level of $5 \%$ is used to determine whether the data in the variables to be analyzed in this study is Poisson distributed or not. If the data is Poisson distributed, then statistical analysis can use a parametric approach. On the contrary, if the data is not Poisson-distributed, then the analysis uses a non-parametric approach. The basis for decision making in Kolmogorov Smirnov test is as follows:

- If Signification value is $>0,05$ then data is normally distributed;

- If the Significant value is $<0.05$ then the data is not normally distributed.

Table 5 - Poisson Distribution Test Results

One-Sample Kolmogorov-Smirnov Test

\begin{tabular}{|ll|l|}
\hline & & StartUp Activities \\
\hline N & & 96 \\
Poisson Parameter & Mean & 5.84 \\
Most Extreme Differences & Absolute & 117 \\
& Positive & .097 \\
& Negative & -117 \\
Kolmogorov-Smirnov Z & & 1.146 \\
Asymp. Sig. (2-tailed) & & .145 \\
\hline
\end{tabular}

a. Test distribution is Poisson.

b. Calculated from data.

Based on the data in Table 5, it was known that Kolmogorov Smirnov Value was 1.146 and had a significance value of $>0.05$, which was 0.145 . It showed that the data was normally distributed or in other words the Poisson-distributed variable.

- Have the assumption of Equidispersion

The Equidispersion assumption shows the conditions under which the mean and variance of the dependent variable are equal. In other words, Equidispersion means that the value of the variance of variable $Y$ that was given by $X$ must be equal to the mean value, that is $V \operatorname{ar}(Y j x)=$ $E(Y j x)=\mu)$

Table 6 - Equidispersion Assumption Test Results

Descriptive Statistics

\begin{tabular}{|l|l|l|l|}
\hline & N & Mean & Variance \\
\hline StartUp Activities & 96 & 5.84 & 6.154 \\
Valid N (listwise) & 96 & & \\
\hline
\end{tabular}

Based on Table 6, it was known that the dependent variable in this study, StartUp Activities had an average value (Mean) of 5.84 and had a variance value of 6.154 . It showed that the assumption of Equidispersion was fulfilled. 
- Have freedom of observation, or in other words, there is no linear relationship between independent variables in the regression model.

Multicollinearity test is used to know whether or not there is a deviation of classical assumption of multicolinearity, specifically, the existence of linear relationship between independent variables in the regression model. Multicolonierity in this study was detected by using Tolerance and Variance Inflation Factor (VIF) values. The presence of multicolonierity is indicated by a cutoff value of Tolerance value of $\leq 0.10$ or VIF value of $\geq 10$. Based on Table 7 , it was known that no independent variable had a Tolerance value less than 0.1 and no independent variable had a VIF value greater than 10 . It showed that there was no correlation between independent variables or it could be concluded that there was no multicolonierity.

Table 7 - Multicollinearity Assumption Test Results

Coefficients $^{a}$

\begin{tabular}{|c|c|c|c|c|c|c|c|}
\hline \multirow[b]{2}{*}{ Model } & \multicolumn{2}{|c|}{ Unstandardized Coefficients } & \multirow{2}{*}{$\begin{array}{l}\text { Standardized Coefficients } \\
\text { Beta }\end{array}$} & \multirow[b]{2}{*}{$\mathrm{t}$} & \multirow[b]{2}{*}{ Sig. } & \multicolumn{2}{|c|}{ Collinearity Statistics } \\
\hline & $\mathrm{B}$ & Std. Error & & & & Tolerance & VIF \\
\hline 1(Constant) & 2.659 & 1,591 & & 1,671 &, 098 & & \\
\hline Financial Capital & -.215 &, 266 &,- 097 &,- 808 & ,421 & ,713 & 1,403 \\
\hline Social Capital & .263 & 273 & 133 & 964 & ,337 &, 544 & 1,839 \\
\hline Human Capital & -.095 & ,298 &,- 042 &,- 318 &, 752 &, 589 & 1,696 \\
\hline Physical Capital &,- 093 &, 300 &,- 042 &,- 311 &, 757 &, 555 & 1,802 \\
\hline Family Cohesiveness &, 830 &, 366 & ,242 & 2,267 & ,026 &, 909 & 1,100 \\
\hline
\end{tabular}

a. Dependent Variable: StartUp Activities

Based on Table 8, it was known that the mean value of the dependent variable was 5.84 and the variance was $6.155\left(2.481^{2}\right)$ which showed the ratio of $6.155: 5.84=1.05$. The Poisson distribution assumed a ratio of 1 , it meant that the Mean and Variance were the same/equal. Therefore, it could be seen that before adding an explanatory variable there was a small amount of Overdispersion.

Table 8 - Overdispersion Test Results

Continuous Variable Information

\begin{tabular}{|ll|l|l|l|l|l|}
\hline & & Minimum & Maximum & Mean & Std. Deviation \\
\hline Dependent Variable & StartUp Activities & 96 & 1 & 9 & 5.84 & 2.481 \\
Covariate & Financial Capital & 96 & 1.00 & 5.00 & 2.5799 & 1.12103 \\
& Social Capital & 96 & 1,00 & 5,00 & 3,0677 & 1,25367 \\
& Human Capital & 96 & 1,00 & 5,00 & 3,5139 & 1,09962 \\
& Physical Capital & 96 & 1,00 & 5,00 & 2,9010 & 1,12769 \\
& Family Cohesiveness & 96 & 1,00 & 5,00 & 4,2630 & .72218 \\
\hline
\end{tabular}

Table 9 - Goodness of Fit Test Results

Goodness of $\mathrm{Fit}^{\mathrm{a}}$

\begin{tabular}{|c|c|c|c|}
\hline & Value & Df & Value/df \\
\hline $\begin{array}{l}\text { Deviance } \\
\text { Scaled Deviance } \\
\text { Pearson Chi-Square } \\
\text { Scaled Pearson Chi-Square } \\
\text { Log Likelihood }^{\mathrm{b}} \\
\text { Akaike's Information Criterion (AIC) } \text { Finite Sample Corrected AIC (AICC) } \\
\text { Bayesian Information Criterion (BIC) } \\
\text { Consistent AIC (CAIC) }\end{array}$ & $\begin{array}{l}113.187 \\
113.187 \\
94.117 \\
94.117 \\
-224.395 \\
460.790 \\
461.734 \\
476.176 \\
482.176 \\
\end{array}$ & $\begin{array}{l}90 \\
90 \\
90 \\
90\end{array}$ & $\begin{array}{l}1.258 \\
1.046\end{array}$ \\
\hline
\end{tabular}

Dependent Variable: StartUp Activities

Model: (Intercept), X1, X2, X3, X4, X5

a. Information criteria are in smaller-is-better form.

b. The full log likelihood function is displayed and used in computing information criteria. 
The Goodness of Fit test can be used to assess how well the model is used in a study. Table 9 showed the df value for the Pearson Chi-Square line of 1.046. It showed that the model in this study met the assumption of Equidispersion. The value of 1 denoted Equidispersion, whereas a value greater than 1 indicated Overdispersion and a value below 1 indicated Underdispersion.

The Omnimbus test is used to determine whether all independent variables are able to improve the model rather than the intercept only model, i.e the model that does not include the independent variable. Table 10 showed the significance value of $>0.05$, that was 0.184 which showed that the overall model was statistically significant. In other words, the addition of all independent variables yielded a statistically significant model.

Table 10 - Omnibus Test Results

Omnibus Test ${ }^{\mathrm{a}}$

\begin{tabular}{|l|l|l|}
\hline Likelihood Ratio Chi-Square & Df & Sig. \\
\hline 7,535 & 5 & .184 \\
\hline
\end{tabular}

Dependent Variable: StartUp Activities

Model: (Intercept), X1, X2, X3, X4, X5

a. Compares the fitted model against the intercept-only model.

Table 11 showed that the variables of Financial Capital, Social Capital, Human Capital, and Physical Capital had significance value of $>0,05$. It meant that the first, second, third, and fourth hypothesis in this study which stated that Financial Capital, Social Capital, Human Capital, and Physical Capital significantly affected StartUp Activities were rejected. Meanwhile, the Family Cohesiveness variable had a significance value of $<0.05$. It meant that the fifth hypothesis that stated that Family Cohesiveness significantly affected the StartUp Activities was received. Exponentiated Value for the Family Cohesiveness variable was 1.025, it meant that the StartUp activities value would be larger by 1.025 for each addition of Family Cohesiveness.

Table 11 - Hypothesis Test Results

Parameter Estimates

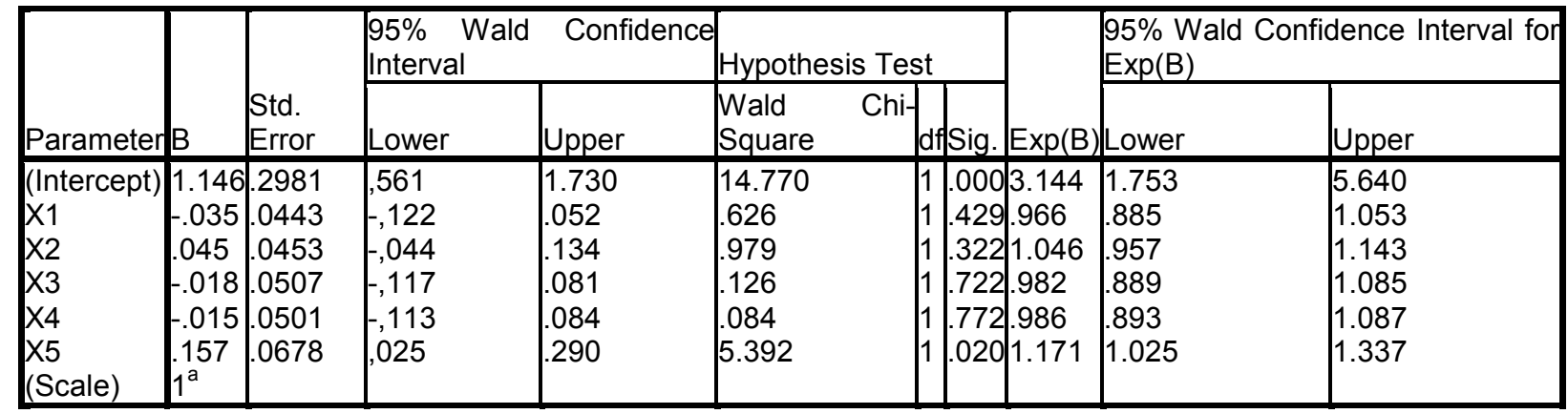

Dependent Variable: StartUp Activities

Model: (Intercept), X1, X2, X3, X4, X5

a. Fixed at the displayed value.

\section{DISCUSSION OF RESULTS}

Schoof (2006) said that it was necessary to distinguish between young entrepreneurs and adult entrepreneurs. It was because young entrepreneurs had different characteristics with more experienced entrepreneurs (Sarasvathy, 1998). Young entrepreneurs had limited resources, minimal life experience and work experience. Young entrepreneurs were confronted with greater obstacles than adult entrepreneurs. To date, there had been an assumption that the main obstacles faced by young entrepreneurs was the difficulty of access to finance or funds. In fact, according to Schoof (2006), cultural and social background, lack of 
entrepreneurship education, frequent changes in rules and administrative frameworks, and lack of help and support in running a business were also categorized as constraints faced young entrepreneurs. The distinction between young entrepreneurs and experienced entrepreneurs was useful in determining the right form of help and support for young entrepreneurs when starting their StartUp business. The variety of constraints faced by young entrepreneurs raised the assumption that support from the family, as the closest party to young entrepreneurs, had an important role in the success of a StartUp business.

This research tried to test whether family support had an influence on the early activities of young entrepreneurs who were just starting business. Based on hypothesis test results, it was known that family social support in the form of financial capital support, social capital support, human capital support and physical capital support did not affect StartUp activities in Malang. Only the family cohesiveness variable which had an influence on StartUp activities of young entrepreneurs in Malang. The results of this study contradicted the initial assumption that the role of family in providing capital could affect the scope of the initial activities undertaken by young entrepreneurs.

As explained by Manalova, et al. (2014) that the role of family support in the development of the StartUp business was complex and multidirectional. Family support could have a positive or negative effect. New StartUp companies were growing in the face of a high risk of failure. Therefore, family support in the form of financial capital, labor, business knowledge, or business network could help young entrepreneurs in minimizing the risks so as to reach the stage of launching. However, family support also turned out to slow the performance of young entrepreneurs. The existence of family protection in the form of capital provision required by young entrepreneurs early in the growth of StartUp business could decrease their strategic orientation, growth orientation, or organizational culture (Bradley et al., 2011). The "comfort" provided by the family would reduce the desire of young entrepreneurs to generate profits quickly, thereby reducing the pressure to better identify market opportunities or finding potential partners that could help the business development. Young entrepreneurs also tended not to be maximized in business planning because they had no urgent interest in external investment that usually required attractive business model proposals.

In contrast to previous research which showed that there was an influence of family social support on StartUp business activities (both positive and negative influence), this research showed that there was no influence of social social support on StartUp business activities. Only the variable of family emotional support or family cohesiveness that had an influence on StartUp activities. The explanation of the results of this study was that not all family supports encouraged to establish a StartUp business by young entrepreneurs, especially in cultures that gave a high value to stability and prestige over a kind of work (Krueger et al., 2013). Most Indonesians considered the job as an entrepreneur as unable to provide a good future and financial stability because of the high risk of failure. In addition, the civil service profession or the employee of a well-known private company was considered to be more prestigious than the entrepreneurs in the social strata of the community, although the income of the entrepreneur was not necessarily smaller than the office work. In the context of this kind of culture, the family would not provide capital support when young entrepreneurs began to pioneer their business. However, in the results of this study, although the family did not provide support in the form of financial capital, labor, business knowledge, or business networks, the family provided emotional support to young entrepreneurs. In other words, the family provided an opportunity for young entrepreneurs to try to develop StartUp business independently. It was slightly different from the Kellermanns \& Eddleston (2004) study which stated that the lack of family support prevented young entrepreneurs from starting a pioneer business in order to avoid family conflicts.

Emotional closeness with family was more necessary in developing StartUp business for young entrepreneurs than physical facilities or support in the form of financial capital, business knowledge, or business network. In fact, $70.8 \%$ of respondents in this study had parents who worked as entrepreneurs. Supposedly, young entrepreneurs could easily obtain financial, knowledge, or business family support from the family when they are developing their StartUp business. However, it turned out that young entrepreneurs relied on their own capabilities in 
developing their StartUp business, despite still having limitations. A total of $44.79 \%$ of respondents were students with business education, management, and economics background. Both of respondents who had a business education background or not, admit that they joined a training to increase their insight in the business world. The basic knowledge in business world was what they use to grow their StartUp business. Young entrepreneurs seeked an access to finance either in the form of debt or capital independently by applying to external parties such as angel investors or banks. Similarly, access to distribution networks or potential customers and physical capital such as places and facilities to run business activities were also obtained by young entrepreneurs without relying on family assistance.

Family social support would be provided when young entrepreneurs were able to demonstrate that his/her pioneer business developing in a positive direction. Therefore, the presence or absence of family social support did not affect the entrepreneurial orientation and growth orientation of young entrepreneurs. As Manalova, et al. (2014) pointed out, the availability of physical capital from the family in the form of location, facility, or distribution network, might not be so important for the scope of initial activity undertaken by young new entrepreneurs. Similarly, the support of family in the form of human capital might be crucial for transgenerational family values transfer and to maintain entrepreneurial intentions, but not so important to the true realization of entrepreneurial initiatives (Laspita et al., 2012). It could be argued that in a society that viewed the entrepreneurial profession as unable to provide stability and prestige, the existence of family social support was considered to be not very important in the development of StartUp business. However, the family did not rule out the members of his family who tried to become young entrepreneurs by providing opportunities and emotional support.

\section{CONCLUSION AND SUGGESTIONS}

This study examined the influence and role of family social support in the form of financial capital, social capital, human capital, physical capital, and family cohesiveness on StartUp activities. Based on the results of the analysis, it was concluded that family social support in the form of financial capital support, social capital support, human capital support and physical capital support did not affect the StartUp activities in Malang. The only variable in this study that influenced the StartUp activities was family cohesiveness. It indicated that in starting a StartUp business, the respondents were strongly influenced by family support in the form of togetherness and family closeness. Emotional closeness was very meaningful to them, especially in the early days they started a business, as well as when they had started running the business. The absence of any influence of financial capital support, social capital support, human capital support and physical capital support indicated that respondents were expecting the assistance from external parties other than families, for example: the investors or the government. It was because of the characteristics of people who still thought that being a permanent employee was much more promising and it was risk-free, when compared to a StartUp business. Therefore, to encourage the growth of StartUp business, the government needs to issue policies which is friendly to StartUp business, such as licensing issues and support from investors in the form of capital or from banking related to easy access to capital.

\section{REFERENCES}

1. Aldrich, H.E., Cliff, J.E. 2003. The pervasive effects of family on entrepreneurship: Toward a family embeddedness perspective. Journal of Business Venturing, 18: 573-596.

2. Bastie, F., Cieply, S., Cussy, P. 2013. The entrepreneur's mode of entry: the effect of social and financial capital. Small Business Economics, 40: 865-877.

3. Blank, S.G. \& B. Dorf. 2012. The Startup Owner's Manual: the step-by-step guide for building a great company. K \& S Ranch.

4. Bradley, S. W., Wiklund, J., Shepherd, D. A. 2011. Swinging a double-edged sword: The effect of slack on entrepreneurial management and growth. Journal of Business Venturing, 26: 537-554. 
5. Calopa, Marina Klacmer, Jelena Horvat, Maja Lalic, 2014. Analysis Of Financing Sources For Start-Up Companies. Management, Vol. 19, 2014, 2, pp. 19-44.

6. Cetindamar, D., Gupta, V., Karadeniz, E.E., Egrican, N. 2012. What numbers tell: the impact of human, family and financial capital on women and men's entry into entrepreneurship in Turkey. Entrepreneurship and Regional Development, 24 (1-2): 29-51.

7. Chua, J.H., Chrisman, J.J., Kellermanns, F., Wu, Z., 2011. Family involvement and new venture debt financing. J. Bus. Ventur. 26, 472-488.

8. Creswell, John W. 2009. Research Design (Qualitative, Quantitative, and Mixed MethodsApproach). Los Angeles: SAGE Publications, Inc. Example", Organizational Dynamics Journal, pp. 8.

9. Danes, S.M., Stafford, K., Haynes, G., Amarapurkar, S.S., 2009. Family capital of family firms: bridging human, social, and financial capital. Fam. Bus. Rev. 22 (3), 199-215.

10. David B. Audretsch and Zoltan J. Acs, New-Firm Startups, Technology, and Macroeconomic Fluctuations Small Business Economics, Vol. 6, No. 6 (Dec., 1994), pp. 439-449.

11. Dyer, W.G., Nenque, E., Hill, E.J. 2014. Toward a theory of family capital and entrepreneurship: antecedents and outcomes. Journal of Small Business Management, 52 (2): 266-285.

12. Edelman, Linda F., Tatiana Manolova, Galina Shirokova, Tatyana Tsukanova, 2016. The impact of family support on young entrepreneurs start-up activities. Journal of Business Venturing 31 (2016) 428-448..

13. Fritsch,M.,2008. Howdoesnewbusinessdevelopmentaffectregionaldevelopment?Introduction tothespecialissues.SmallBus.Econ.30(1),1-14.

14. Granovetter, M., 1992. Problems of Explanation in Economic Sociology. In: Nohria, N., Eccles, R. (Eds.), Networks and Organizations: Structure, Form, and Action. Harvard Business School Press, Boston, MA, pp. 25-56.

15. Grichnik, D., Brinckmann, J., Singh, L., Manigart, S. 2014. Beyond environmental scarcity: human and social capital as driving forces of bootstrapping activities. Journal of Business Venturing, 29: 310-326.

16. Grossman, E.B., Yli-Renko, H., Janakiraman, R., 2012. Resource search, interpersonal similarity, and network tie valuation in nascent entrepreneurs' emerging networks. J. Manag. 38 (6), 1760-1787.

17. Hoang, H., Antoncic, B., 2003. Network-based research in entrepreneurship: a critical review. J. Bus. Ventur. 18 (2), 165-187.

18. Kellermanns, F.W., Eddleston, K., 2004. Feuding families: when conflict does a family firm good. Enterp. Theory Pract. 28 (3), 209-228. http://dx.doi.org/10.1111/j.15406520.2004.00040.x.

19. Kim, P.H., Longest, K.C., Aldrich, H.E., 2013. Can you lendme a hand? Task-role alignment of social support for aspiring business owners.Work. Occup. 40 (3), 213-249.

20. Koellinger,P.D.,Thurik,R.,2012.Entrepreneurshipandthebusinesscycle.Rev.Econ.Stat.94(4), 1143-1156.

21. Koropp, C., Grichnik, D., Kellermanns, F., 2013. Financial attitudes in family firms: the moderating role of family commitment. J. Small Bus. Manag. 51 (1), 114-137.

22. Krueger, N., Liñán, F., Nabi, G. 2013. Cultural values and entrepreneurship. Entrepreneurship \& Regional Development, 25 (9-10): 703-707.

23. Laspita, S., Breugst, N., Heblich, S., Patzelt, H. (2012). Intergenerational transmission of entrepreneurial intentions. Journal of Business Venturing, 27 (4): 414-435.

24. Manolova, T., G. Shirokova, T. Tsukanova, L. Edelman. 2014. The Impact Of Family Support On Young Nascent Entrepreneurs' Start-Up Activities: A Family Embeddedness Perspective. Working Paper St. Petersburg State University Graduate School of Management.

25. Newbert, S.L., Tornikoski, E.T., Quigley, N.R., 2013. Exploring the evolution of supporter networks in the creation of new organizations. J. Bus. Ventur. 28, 281-298.

26. Parinduri, Rasyad A., 2014. Family Hardship And The Growth Of Micro And Small Firms In Indonesia. EconPapers. 
27. Ries, E. 2011.The Lean Startup: How Today's Entrepreneur Use Continuous. Crown Publishing Group.

28. Rodriguez, P., Tuggle, C.S., Hackett, S.M., 2009. An exploratory study of howpotential "family and household capital" impacts newventure start-up rates. Fam. Bus. Rev.22, 259272.

29. Spence, Laura J., René Schmidpeter, André Habisch, 2003. Assessing Social Capital: Small and Medium Sized Enterprises in Germany and the U.K. Journal of Business Ethics 47: 17-29.

30. Innovation to Create Radically Successful Business. Crown Business. Jumlah Startup Indonesia Tertinggi di Asia Tenggara, https://marketplus.co.id/2017/03/jumlah-startupindonesia-tertinggi-di-asia-tenggara/, 2017.

31. Sarasvathy S. D. 1998. How do firms come to be? Towards a theory of the prefirm. http://www.effectuation.org/sites/default/files/research_papers/babson97-how-firms-cometo-be.pdf

32. SEED Working Paper No. 76, Series on Youth and Entrepreneurship, Stimulating Youth Entrepreneurship: Barriers and incentives to enterprise start-ups by young people, Ulrich Schoof (2006), http://www.ilo.org/public/libdoc/ilo/2006/106B09_94_engl.pdf

33. Sorensen, J.B., 2007. Closure and exposure: mechanisms in the intergenerational transmission of self-employment. In: Ruef, M., Lounsbury, M. (Eds.), Research in the Sociology of Organizations, vol. 25. Emerald Group Publishing Limited, Bradford, pp. 83124.

34. Steier, L.P., Chua, J.H., Chrisman, J.J. 2009. Embeddedness perspectives of economic action within family firms. Entrepreneurship Theory and Practice November: 1157-1167.

35. Winborg, J., Landström, H., 2001. Financial bootstrapping in small businesses: examining small business managers' resource acquisition behaviors. J. Bus. Ventur. 16(3), 235-254.

36. Apa Itu Startup? Bgmn Perkembangan Dunia Bisnis Startup di Indonesia?, https://www.maxmanroe.com/apa-itu-startup-bgmn-perkembangan-dunia-bisnis-startup-diindonesia.html, 2016. 